\title{
ANALISIS TARIF PREMI DAN ASUMSI LOADING PADA PRODUK ASURANSI DWIGUNA BEASISWA
}

\author{
Ira Rosianal Hikmah ${ }^{1 *}$, Yulial Hikmah ${ }^{2}$ \\ ${ }^{1}$ Sekolah Tinggi Sandi Negara, ${ }^{2}$ Program Pendidikan Vokasi Universitas Indonesia \\ Email: ${ }^{1}$ ira.rosianal@stsn-nci.ac.id, ${ }^{2}$ yulialhikmah47@ui.ac.id \\ *Penulis korespondensi
}

\begin{abstract}
Based on data from Badan Pusat Statistik (BPS), the number of Indonesia's population has consistently increased every year. This will cause several problems, one of them is public health. Health problems that occur cause some risks that cause losses. Therefore, one way to reduce the impact of these risks is insurance. This study analyzes how the process of forming premium prices with loading assumptions that are in accordance with existing assumptions in order to meet the criteria of equitable to the client, deliverable by the agent, and profitable to the company. This research uses a quantitative research approach. The population in this study was all Sum Insured (SI) while the sample was 1000 SI male sex. The data used in this study are secondary data that is data from an ABC insurance company in Indonesia, literature study through books, journal references, and previous research. The results of this study are the calculation of premiums by the methods used by the company more efficiently when compared with formulas in accordance with the theory. Although the price of a premium is more expensive using the company method, it is not significantly different. If using the company method, the sum insured used is the sum insured from death benefit whereas the theory is the average of claims incurred at that age. The fees charged are still fairly reasonable in accordance with the rules of setting the price of insurance premiums. In addition, the use of CSO 80 tables and Reinsurance Rates that have been adjusted to the company's interest rate of $5 \%$ in accordance with the expected cash value desired by the company.
\end{abstract}

Keywords: equitable to the client, deliverable by the agent, profitable to the company, CSO 80 table, reinsurance rate

\begin{abstract}
Abstrak. Berdasarkan data Badan Pusat Statistik (BPS) jumlah penduduk Indonesia konsisten mengalami peningkatan setiap tahunnya. Hal ini akan menimbulkan beberapa permasalahan salah satunya kesehatan masyarakat. Masalah kesehatan yang terjadi menyebabkan timbulnya beberapa risiko yang menyebabkan kerugian. Oleh karena itu, salah satu cara untuk mengurangi dampak dari risiko tersebut adalah dengan berasuransi. Penelitian ini menganalisis bagaimana proses terbentuknya harga premi dengan asumsiasumsi loading yang sesuai dengan asumsi-asumsi yang ada agar memenuhi kriteria equitable to the client, deliverable by the agent, dan profitable to the company. Penelitian ini menggunakan pendekatan penelitian kuantitatif. Populasi dalam penelitian ini adalah seluruh Sum Insured (SI) sedangkan sampelnya adalah 1000 SI berjenis kelamin pria. Data yang digunakan dalam penelitian ini adalah data sekunder yaitu data dari suatu perusahaan asuransi $\mathrm{ABC}$ di Indonesia, studi pustaka melalui buku, referensi jurnal dan penelitian terdahulu. Hasil penelitian ini adalah perhitungan premi dengan metode yang digunakan perusahaan lebih efisien jika dibandingan dengan formula sesuai dengan teori.
\end{abstract}


Walaupun harga premi lebih mahal menggunakan metode perusahaan, namun tidak berbeda signifikan. Jika menggunakan metode perusahaan, uang pertanggungan yang digunakan adalah uang pertanggungan dari death benefit sedangkan dengan teori adalah rata-rata dari klaim yang terjadi pada usia tersebut. Biaya yang dikenakan pun masih terbilang wajar sesuai dengan kaidah dari penetapan harga premi asuransi. Selain itu, penggunaan tabel CSO 80 dan Rate Reasuransi yang sudah disesuaikan dengan interest rate perusahaan sebesar 5\% sesuai dengan harapan nilai tunai yang diinginkan perusahaan.

Kata Kunci: equitable to the client, deliverable by the agent, profitable to the company, tabel CSO 80, rate reasuransi

\section{PENDAHULUAN}

Menurut data dari Badan Pusat Statistik (BPS) tahun 2010 dari hasil sensus penduduk menyatakan bahwa laju pertumbuhan penduduk di Indonesia meningkat sebesar $1.49 \%$ pertahunnya [1]. Hal ini membuktikan bahwa jumlah penduduk di Indonesia konsisten mengalami peningkatan setiap tahunnya. Menurut World Population data sheet 2013, Indonesia merupakan Negara ke 5 di dunia dengan jumlah penduduk terbanyak, yaitu 249 juta. Di antara negara Asean, Indonesia merupakan penduduk terbanyak dari 9 Negara anggota lain dengan angka fertilitas atau Total Fertility Rate (TFR) 2,6. Indonesia masih berada diatas ratarata TFR negara Asean yaitu 2,4. Sedangkan menurut Badan Perencana Pembangunan Nasional (Bappenas) dan Badan Pusat Statistik (BPS) memperkirakan bahwa penduduk Indonesia pada Tahun 2020 akan mencapai 271,1 juta jiwa.

Kondisi pertumbuhan penduduk yang tidak dapat ditekan akan menimbulkan beberapa permasalahan salah satunya kesehatan masyarakat. Hal ini karena sebagian masyarakat Indonesia tidak mendapatkan layanan kesehatan, baik yang diberikan oleh pemerintah atau pribadi akibat biaya kesehatan yang terus meningkat. Menurut Kementerian Kesehatan Republik Indonesia tahun 2015, hal ini menimbulkan ketidakseimbangan antara laju pertumbuhan dengan tingkat kesehatan. Masalah kesehatan yang terjadi menyebabkan timbulnya beberapa risiko yang menyebabkan kerugian. Risiko yang berdampak buruk dapat mengakibatkan seseorang atau kelompok tertentu mengalami kehilangan kemampuan baik dari segi materi maupun fisik. Risiko tersebut terkadang tidak bisa dikendalikan atau hindari. Oleh karena itu, untuk mengurangi dampak dari risiko tersebut maka risiko tersebut harus dibagi. Salah satu caranya dengan berasuransi. Menurut LOMA (Life Office Management Association), asuransi yang berkaitan dengan hidup mati dan kesehatan seseorang dinamakan asuransi jiwa [2] [3].

Pihak yang memberikan jaminan adalah pihak penanggung (perusahaan asuransi) dan pihak yang membayar iuran adalah pihak tertanggung (nasabah) [4]. Perjanjian asuransi disebut juga polis. Iuran yang dibayar tertanggung disebut premi. Uang jaminan yang dibayar penanggung adalah manfaat atau uang pertanggungan. Manfaat diberikan penanggung ketika diterima laporan kejadian yang dialami tertanggung. Laporan kejadian ini disebut klaim. Kejadian yang dimaksud adalah kejadian yang diasuransikan sebagaimana tertera dalam polis. Pada asuransi konvensional, uang pertanggungan yang dijamin disebut sebagai manfaat proteksi [5] [6]. Adapun dalam penetapan premi secara teori harus memenuhi kriteria equitable to the client, deliverable by the agent, dan profitable to the company [4]. 
Prinsip yang pertama yaitu tarif premi yang equitable to the client adalah setiap tertanggung harus dikenakan tarif premi yang adil. Dalam hal ini, bagi tertanggung dengan risiko yang lebih tinggi, akan dikenakan tarif premi yang lebih tinggi, begitu pula sebaliknya. Prinsip yang kedua yaitu tarif premi harus deliverable by the agent, hal ini berkaitan dengan penjualan suatu produk asuransi, jika tarif preminya terlalu rendah maka penjual tidak akan mau untuk menjual produk asuransi karena akan berdampak pada pendapatan komisi yang kecil. Namun, jika produk asuransi dijual dengan tarif yang lebih tinggi maka penjual akan mendapatkan komisi yang lebih besar tetapi dengan risiko penjual akan mengalami kesulitan dalam mendapatkan calon nasabah. Oleh karena itu, tarif premi yang ditetapkan harus sewajar mungkin dan juga harus dapat bersaing dengan tarif premi perusahaan lain. Prinsip yang ketiga adalah profitable to the company yaitu tarif premi yang ditetapkan harus cukup untuk membayar manfaat yang akan datang (klaim), membiayai seluruh operasional perusahaan, dan juga dapat memberikan profit bagi perusahaan [4].

Berdasarkan penjelasan sebelumnya, penelitian ini menganalisis bagaimana proses terbentuknya harga premi dengan asumsi-asumsi loading yang sesuai dengan asumsi-asumsi yang ada agar memenuhi kriteria-kriteria tersebut.

\section{METODE PENELITIAN}

Penelitian ini menggunakan pendekatan penelitian kuantitatif. Variabel penelitian ini adalah nilai premi sebagai variabel dependen $(\mathrm{Y})$; interest rate $(\mathrm{X} 1)$, loading $(\mathrm{X} 2)$, dan agency compentation (X3) sebagai variabel independen (X). Populasi dalam penelitian ini adalah seluruh Sum Insured (SI) sedangkan sampelnya adalah 1000 SI berjenis kelamin pria. Data yang digunakan dalam penelitian ini adalah data sekunder yaitu data dari suatu perusahaan asuransi $\mathrm{ABC}$ di Indonesia, studi pustaka melalui buku, referensi jurnal dan penelitian terdahulu, serta dokumen lainnya yang berhubungan dengan penelitian ini baik secara offline maupun online.

Berikut ini merupakan langkah umum dalam menentukan harga premi asuransi jiwa:

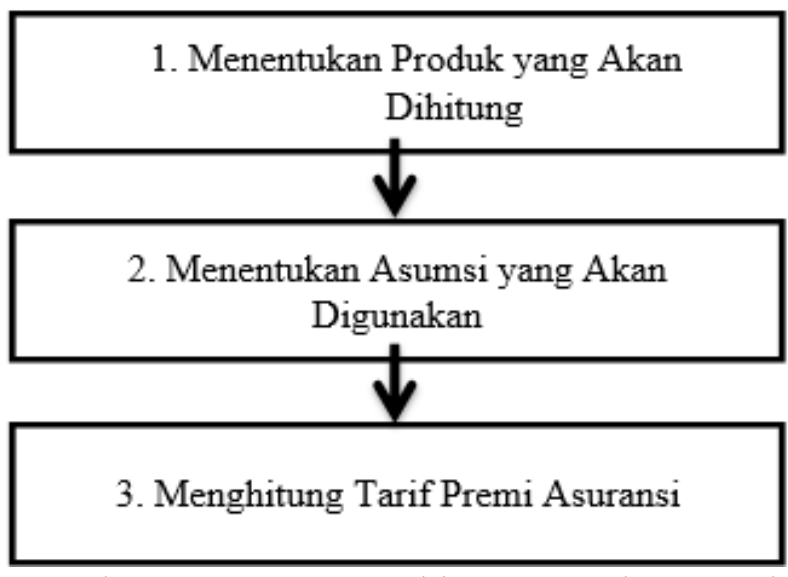

Gambar 1. Proses menghitung premi asuransi 


\section{HASIL DAN PEMBAHASAN}

\subsection{Deskripsi Produk}

Langkah awal dalam menghitung premi asuransi adalah menentukan produk yang akan dihitung. Berikut ini merupakan penjelasan dari produk asuransi yang digunakan dalam penelitian ini [7]:

1. Spesifikasi Umum Produk
a. Nama Pemasaran
: Asuransi Dwiguna Beasiswa
b. Usia Masuk Anak/Penerima Manfaat
$: 0-15$ tahun
Tertanggung/ Pemegang Polis
: $16-70$ tahun
c. Masa Asuransi
: s/d usia anak 21 tahun
d. Mata Uang
: Rupiah

2. Manfaat Produk
a. Cacat tetap total (tertanggung)
b. Meninggal
Anak/penerima manfaat
: Pembebasan premi dan manfaat tetap berjalan
$R p$ 20.000.000 dividen akhir kontrak (jika ada)
Tertanggung/ penerima polis
c. Jatuh tempo (usia anak 21 tahun)
: Pembebasan premi dan manfaat tetap berjalan akhir kontrak (jika ada)
d. Terminal Illness
e. Hidup di masa asuransi dapat dilihat pada Tabel 1.
Putus kontrak
Bebas premi (paid-up)
: 100\% uang pertanggungan ditambah dividen tahun ke-1 dan setelah masa tenggang 45 hari Pinjaman polis
: 50\% uang pertanggungan
: Dividen tahunan (tidak dijamin) dan penjelasan
: Nilai tunai mulai akhir tahun ke-1
: Polis diubah ke bentuk dwiguna setelah akhir
: Maksimum $80 \%$ dari nilai tunai

Tabel 1. Pembayaran Manfaat Hidup (\% dari Uang Pertanggungan)

\begin{tabular}{ccccc}
\hline \multicolumn{5}{c}{ Usia Masuk } \\
& $0-3$ & $4-9$ & $10-12$ & $13-15$ \\
\hline Usia 6 & $10 \%$ & & & \\
\hline Usia 12 & $15 \%$ & $15 \%$ & $25 \%$ \\
\hline Usia 15 & $25 \%$ & $25 \%$ & $50 \%$ & $50 \%$ \\
\hline Usia 18 & $50 \%$ & $50 \%$ & $25 \%$ & $25 \%$ \\
\hline Usia 19 & $25 \%$ & $25 \%$ & $25 \%$ & $25 \%$ \\
\hline Usia 20 & $25 \%$ & $25 \%$ & $100 \%$ & $100 \%$ \\
\hline Usia 21 & $100 \%$ & $100 \%$ & $225 \%$ & $200 \%$ \\
\hline Total & $250 \%$ & $240 \%$ & &
\end{tabular}

Langkah selanjutnya adalah menentukan asumsi-asumsi yang dibutuhkan. Ketentuan cara pembayaran dan metode pembayaran premi produk ini sebagai berikut:

a. Masa Pembayaran : Tunggal, 5, 10, atau 21 tahun 
b. Metode Pembayaran : Tahunan, enam bulanan, tiga bulanan, atau bulanan

c. Masa Tenggang : 45 hari

d. Penyesuaian Rate Premi

Laki-laki : Tidak ada penyesuaian

Perempuan : Laki-laki dikurangi 3 tahun

Asumsi tabel mortalita yang digunakan dalam penelitian ini dapat dilihat pada Tabel 2.
a. Tingkat bunga
: 7\% p.a. (berdasarkan pengalaman perusahaan)
b. Komisi (\% premi) : $25 \%$ (berdasarkan ketetapan perusahaan)

Tabel 2. Tabel Penggunaan Rate Mortalita

\begin{tabular}{cccc}
\hline Tabel Mortalita & Usia & $\begin{array}{c}\text { Anak/Penerima } \\
\text { Manfaat }\end{array}$ & $\begin{array}{c}\text { Tertanggung/Pemegang } \\
\text { Polis }\end{array}$ \\
\hline CSO 80 & $16-53$ & $70 \%$ & $70 \%+0,15$ permill \\
\hline Rate Asuransi & $54-99$ & $100 \%$ & $100 \%+0,15$ permill \\
\hline
\end{tabular}

Berdasarkan Tabel 2, penelitian ini menggunakan tabel CSO 80 karena tabel tersebut masuk sesuai dengan nilai tunai yang terbentuk bagi perusahaan. Rate Reasuransi juga digunakan karena pada usia tersebut perusahaan beranggapan bahwa klaim yang diajukan di ambang batas retensi perusahaan. Dengan demikian, perusahaan mengalihkannya sebagian kepada perusahaan reasuransi.

Asumsi-asumsi lain dalam penelitian ini adalah:

a. Premi tunggal : Min (3,25\% masa asuransi, 6,5\%)

b. Premi Lanjutan

Tahun ke-1 : Min (1\% masa pembayaran premi, 30\%)

Tahun ke-2 : Min (1\% masa pembayaran premi, 30\%)

c. Diskon premi

Reguler $: 5 \%$ premi (masa pembayaran $=$ masa asuransi)

Lain-lain $\quad: 0 \%$ premi

d. Profit Margin : $12 \%$ premi

e. Rata-rata uang pertanggungan:

Tabel 3. Tabel Rata-Rata Uang Pertanggungan

\begin{tabular}{cl}
\hline $\begin{array}{c}\text { Masa Pembayaran } \\
\text { Premi }\end{array}$ & $\begin{array}{c}\text { Rata-rata Uang } \\
\text { Pertanggungan }\end{array}$ \\
\hline Tunggal & $R p 25.000 .000$ \\
\hline 5 & $R p 20.000 .000$ \\
\hline 10 & $R p 20.000 .000$ \\
\hline 21 & $R p 25.000 .000$ \\
\hline
\end{tabular}

Langkah selanjutnya adalah menghitung tarif premi, baik premi netto maupun premi bruto.

a. Premi Netto

$$
\begin{gathered}
P_{\text {Netto }}=\left[P V_{\text {death }}+P V_{\text {terminal illness }}+P V_{\text {death after terminal illness }}+P V_{\text {funeral for prayer }}\right. \\
\left.+P V_{\text {funeral for beneficary }}\right] \times \frac{\mathrm{SI}}{\text { death benefit }}
\end{gathered}
$$




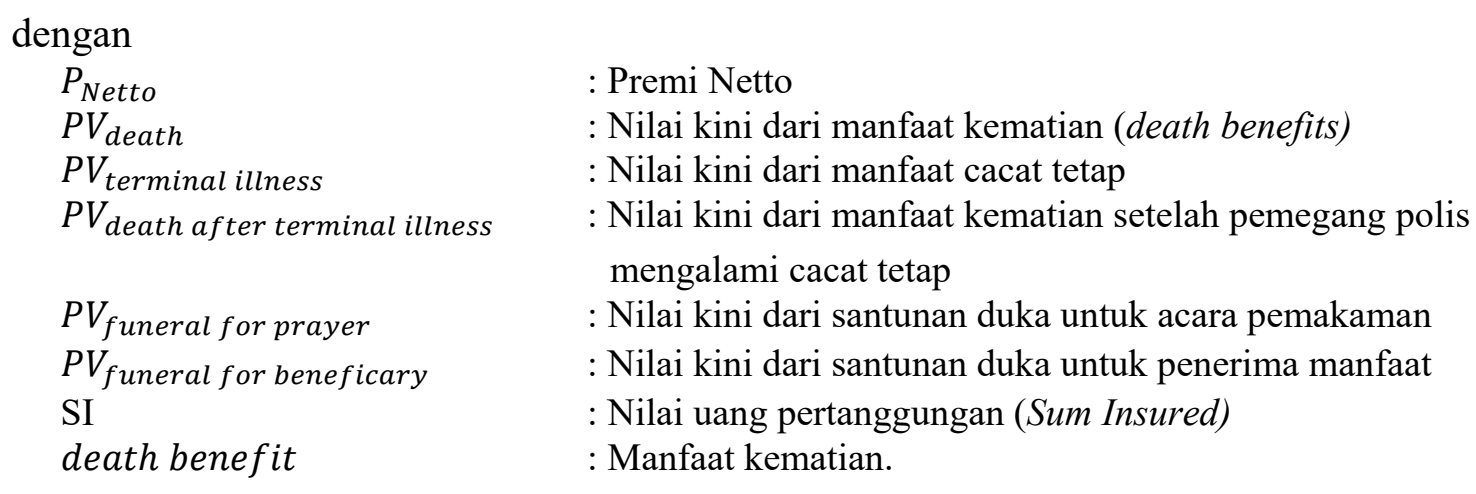

b. Premi Bruto

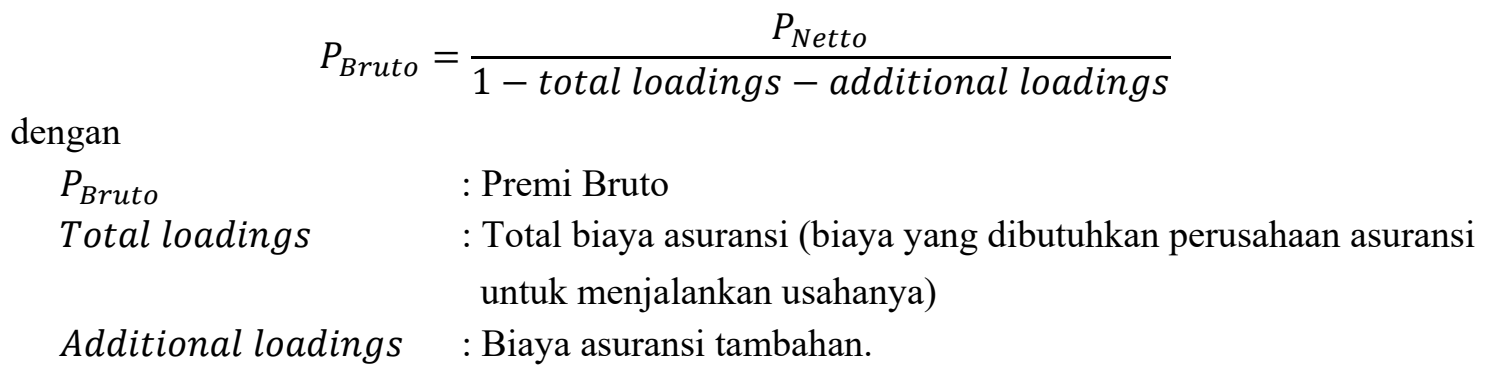

\subsection{Analisis Produk}

Untuk menganalisis produk, dilakukan perhitungan untuk suatu ilustrasi contoh kasus. Misalkan seorang pria berusia 28 tahun membeli asuransi jiwa dwiguna beasiswa dengan usia anak 10 tahun. Ia bekerja sebagai pegawai bank dengan penghasilan $R p 12.000 .000$ per bulan dan tidak merokok. Riwayat penyakit yang ada adalah Asma bronkial (sesak napas karena asma) dan Apendisitis (radang usus buntu) dengan status Appendectomy (operasi usus buntu) telah dilakukan pada tahun 2011 di Klinik Mitra Keluarga Bekasi Barat (bukti surat dokter dan rumah sakit lengkap bersama dokumentasi Apendiks (umbai cacing/ organ yang meradang pada Sekum) yang sudah diangkat. Hal demikian memberikan kemudahan ketika seorang underwiter melakukan seleksi risiko calon tertanggung. Ia memilih untuk melakukan pembayaran premi secara bulanan selama 5 tahun. Berdasarkan kasus di atas, dapat dihitung dan dianalisis sehingga diperoleh beberapa pertanyaan berikut:

a. Berapa premi yang harus Bapak X bayar?

b. Berapa Nilai Tunai yang akan terbentuk ketika anak masuk usia 21 tahun?

c. Apa yang akan Bapak X (pemegang polis/tertanggung) dapatkan apabila meninggal dunia sebelum anak berulang tahun di usia ke 21 tahun?

d. Apa yang akan Bapak X dapat apabila anak/penerima manfaat meninggal dunia sebelum selesai masa kontrak?

Berikut ini data aktuaria dan asumsinya berdasarkan contoh kasus di atas:
a. Usia tertanggung
: 28 tahun
b. Usia anak
: 10 tahun
c. Masa pembayaran premi
: 5 tahun
d. Tingkat bunga
: $7 \%$
e. Tabel Mortalita
: CSO 80
f. Masa asuransi
: 11 tahun 
g. Mata uang : Rupiah

h. Grace Period : 45 hari

i. Asumsi biaya:

- $\alpha=0,05 \%$

- $\beta=49,86 \%$

- $\gamma=12 \%$

Perhitungan premi dengan metode perusahaan, diperoleh:

1. Manfaat yang diberikan
Death
$=R p 100.000 .000$
Terminal Illness
$=R p 50.000 .000$
Death After Terminal Illness $=R p 50.000 .000$
Funeral for Payer
$=R p 20.000 .000$
Funeral for Benaficary
$=R p 20.000 .000$.

2. PV Manfaat usia 28 tahun
$P V_{\text {death }}$
$=R p 133.333$
$P V_{\text {terminal illness }}$
$=R p 0$
$P V_{\text {death after terminal illness }}=R p 0$
$P V_{\text {funeral }}$ for prayer $\quad=R p 0$
$P V_{\text {funeral for beneficary }} \quad=R p 0$.

Sehingga premi netto dan brutonya adalah

$$
\begin{aligned}
& P_{\text {Netto }}=R p 113.000 / \text { bulan } \\
& P_{\text {Bruto }}=R p 298.000 / \text { bulan } .
\end{aligned}
$$

Perhitungan $P_{\text {Netto }}$ secara teori:

$$
\begin{aligned}
& P_{\text {Netto }}=R p 112.936 / \text { bulan } \\
& P_{\text {Bruto }}=R p 252.612 / \text { bulan } .
\end{aligned}
$$

Selanjutnya, karena anak berusia 10 tahun maka nilai tunai yang terbentuk hingga usia anak 21 tahun adalah sebesar $225 \%$ dari pertanggungannya sehingga jika dibayarkan lumpsum:

$$
N T=225 \% \times R p 20.000 .000=R p 45.000 .000 .
$$

Sedangkan jika dibayarkan secara bertahap, maka diperoleh:

$$
\begin{aligned}
& N T_{15}=25 \% \times R p 20.000 .000=R p 5.000 .000 \\
& N T_{18}=50 \% \times R p 20.000 .000=R p 10.000 .000 \\
& N T_{19}=25 \% \times R p 20.000 .000=R p 5.000 .000 \\
& N T_{20}=25 \% \times R p 20.000 .000=R p 5.000 .000 \\
& N T_{21}=100 \% \times R p 20.000 .000=R p 20.000 .000
\end{aligned}
$$

Selanjutnya, sesuai dengan perjanjian dalam polis tentang produk ini, jika pemegang polis meninggal dunia sebelum anak berulang tahun di usia ke-21 tahun (habis kontrak), maka akan dikenakan pembebasan premi dengan manfaat masih terus berjalan. Akan tetapi, jika anak/penerima manfaat meninggal dunia maka akan diberikan pengembalian premi dengan bunga ditambah $R p 20.000 .000$. 
Perhitungan premi dengan metode yang digunakan perusahaan pada kasus di atas diperoleh:

$$
\begin{array}{ll}
P_{\text {Netto }} & =R p 113.000 / \text { bulan } \\
P_{\text {Bruto }} & =R p 298.000 / \text { bulan }
\end{array}
$$

Jika diterapkan perhitungan premi secara teori dengan menggunakan tabel komutasi, yang diperoleh dari tabel mortalita CSO 80, maka diperoleh:

$$
\begin{aligned}
P_{\text {Netto }} \text { teori } & =20.000 .000 \times\left(\frac{M_{28}-M_{39}+D_{39}}{N_{28}-N_{39}}\right) \\
& =20.000 .000 \times\left(\frac{31.840-28.892+142.864}{4.573 .375-2.421 .545}\right) \\
& =20.000 .000 \times\left(\frac{145.812}{2.151 .830}\right) \\
& =1.355 .237,17 / \text { tahun } \\
& =112.936,43 / \text { bulan }
\end{aligned}
$$

sedangkan $P_{\text {Bruto }}$ teori :

$$
\begin{aligned}
P_{\text {Bruto }_{\text {teori }}} & =\left(\frac{1.355 .237,17 \times(1+0,12)}{(1-0,4987)-\left(\frac{0,005}{8,6718}\right)}\right) \\
& =3.031 .546 / \text { tahun } \\
& =252.628,83 / \text { bulan. }
\end{aligned}
$$

Jika dibandingkan hasil antar kedua metode tersebut, hasil premi tidak berbeda signifikan. Namun dari segi keefektifian dan efisiensi, penggunaan metode perhitungan yang digunakan oleh perusahaan dengan menggunakana asumsi loading lebih baik walaupun premi yang diperoleh sedikit lebih mahal dibandingkan dengan perhitungan premi secara teoritis.

\section{KESIMPULAN}

Perhitungan premi dengan metode yang digunakan perusahaan lebih efisien jika dibandingan dengan formula sesuai dengan teori. Walaupun harga premi lebih mahal menggunakan metode perusahaan, namun tidak berbeda signifikan. Pada dasarnya prinsip perhitungan premi yang digunakan perusahaan dengan teori adalah sama yaitu asuransi dibagi dengan anuitasnya, yang membedakan adalah penggunaan nilai pertanggungan dan faktor diskontonya. Jika menggunakan metode perusahaan, uang pertanggungan yang digunakan adalah uang pertanggungan dari death benefit sedangkan dengan teori adalah rata-rata dari klaim yang terjadi pada usia tersebut. Asumsi-asumsi yang digunakan merupakan asumsi biaya berdasarkan pengalaman perusahaan dan harapan keuntungan yang perusahaan ingin capai. Biaya yang dikenakan pun masih terbilang wajar. Sesuai dengan kaidah dari penetapan harga premi asuransi.

Penggunaan tabel CSO 80 dan Rate Reasuransi yang sudah disesuaikan dengan interest rate perusahaan sebesar 5\% sesuai dengan harapan nilai tunai yang diinginkan perusahaan. Tabel CSO 80 digunakan untuk usia 16-53 tahun dan Rate Reasuransi digunakan untuk usia di atasnya. Hal ini dikarenakan perusahaan menganggap bahwa klaim yang terjadi di atas usia 53 tahun melebihi retensi perusahaan. Oleh karena itu, dialihkan sebagian ke perusahaan reasuransi. 


\section{REFERENSI}

[1] T. E. Rahayu, "Pertumbuhan dan Persebaran Penduduk Indonesia (Hasil Sensus Penduduk 2010)," 2010. [Online]. Available: https://media.neliti.com/media/publications/49963-IDpertumbuhan-danpersebaran-penduduk-indonesia.pdf. [Diakses 5 Agustus 2019].

[2] R. Mehr dan E. Cammack, Principles of Insurance, 6th edition, Editor: Illnois: R.D. Irwin, 1976.

[3] H. Salim, Dasar-Dasar Asuransi, Jakarta: Raja Grafindo Persada, 2000.

[4] K. Wollner, Richard J. Scislowski J.D., W. Jeffrey Woodward, How to Draft and Interpret Insurance Policies, International Risk Management Institute, Inc., 2010.

[5] T. Futami, Matematika Asuransi Jiwa bagian 1, Tokyo: OLICD Center, 1993.

[6] T. Futami, Matematika Asuransi Jiwa bagian 2, Tokyo: OLICD Center, 1994.

[7] M. Iqbal, "Pricing Asuransi Unit-Linked dengan Manfaat Terjamin," Universitas Indonesia, Depok, 2016. 